
\title{
КОРЕКЦІЯ МЕТАБОЛІЧНИХ ПОРУШЕНЬ ПРИ КОНСЕРВАТИВНОМУ ЛІКУВАННІ ПОЗАМАТКОВОЇ ВАГІTHOCTI
}

\begin{abstract}
Резюме. Згідно з даними епідемічних досліджень, в економічно розвинених країнах частота позаматкових вагітностей (ПВ) становить 1,2-2,0 \% від загальної кількості вагітностей і 0,8-2,4 \% - від пологів та займає 4 місце серед причин материнської смертності.

Мета дослідження - вивчити токсичний вплив метотрексату на експериментальних тварин залежно від дози та оцінити захисний ефект кальцію фолінату після одноразового та дворазового введень метотрексату.

Матеріали і методи. Роботу виконано на 54 лабораторних білих щурах, яких утримували у стандартних умовах віварію. Було

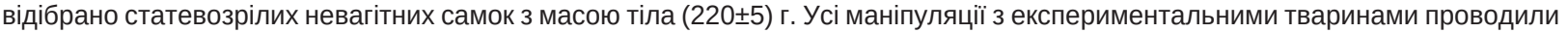
із дотриманням правил Європейської конвенції про захист хребетних тварин, що використовуються для дослідних та інших наукових цілей (Страсбург, 1986). Піддослідних тварин поділили на 9 груп по 6 тварин.

Результати досліджень та їх обговорення. Ми вивчили індекс ендогенної інтоксикації у 54 дослідних щурів на фроні одноразового та дворазового введень метотрексату в дозі 1 мг/кг на 3 та 7 доби. Досліджено захисну дію кальцію фролінату в дозі 0,1 мг/кг, який вводили через 24 год після ін'єкції метотрексату. Даний експеримент показав збільшення рівня кислої та лужної фоссратаз у щурів при внутрішньом'язовому введенні метотрексату при позаматковій вагітності. Використання кальцію фолінату зменшує побічну дію основного препарату, що показано достовірною різницею між дослідними групами щурів.

Висновки. Даний експеримент показав збільшення рівня кислої та лужної фоссратаз у щурів при внутрішньом'язовому введенні метотрексату при позаматковій вагітності. Корекцію метаболічних порушень при консервативному лікуванні позаматкової вагітності можливо проводити антидотом метотрексату - кальцію фролінатом.
\end{abstract}

Ключові слова: метотрексат; кисла фросфатаза; лужна фросфратаза; кальцію сролінат.

встУп Згідно з даними епідемічних досліджень, в економічно розвинених країнах частота позаматкових вагітностей (ПВ) становить 1,2-2,0 \% - від загальної кількості вагітностей і 0,8-2,4 \% - від пологів та займає 4 місце серед причин материнської смертності [1]. Число хворих, госпіталізованих у гінекологічний стаціонар із підозрою на ектопічну вагітність, варіює в межах 1-12 \%. [2].

Медикаментозне лікування трубної вагітності метотрексатом на сучасному етапі є реальною альтернативою ендоскопічної сальпінготомії у певної групи пацієнток [13]. Основні переваги медикаментозного лікування полягають у відсутності ризику, пов'язаного з оперативним втручанням і загальною анестезією, простоті виконання, нижчої вартості. Необхідною умовою $€$ встановлення діагнозу позаматкової вагітності неінвазивними методами.

Побічні ефекти метотрексату пов'язані з депресією кістково-мозкового кровотворення, а також із токсичною дією на слизові оболонки (особливо шлунково-кишкового тракту) і шкірні покриви, печінку, легені. Зниження концентрації гемоглобіну і тромбоцитів спостерігаються, як правило, на 5-12 день, лейкопенія - на 4-7 і на 12-21 дні після введення препарату [14]. Дерматологічні ефректи метотрексату включають почервоніння, свербіння, посилення пігментації, підвищення чутливості шкіри до ультраоріолетового випромінювання і, рідше, алопецію [3].

Найчастіше при лікуванні ПВ метотрексатом бувають такі побічні едекти, як стоматит, гастрит і ентеропатія (діарея), а також транзиторне підвищення рівня печінкових трансаміназ, що свідчить про ураження печінки. Так, при чотириразовому внутрішном'язовому введенні метотрексату в дозі 1,0 мг/кг подібні ускладнення зареєстровано у $50 \%$ хворих [6].

Одними з маркерів ушкодження пенічки слугують лужна і кисла фоссратази.

Лужна фоссратаза (ЛФ) - фрермент, що впливає на процес відкладання кальцію в кістковій тканині, а також на транспорт і обмін ліпідів. ЛФ надзвичайно поширена у тканинах людини, особливо в слизовій оболонці кишеч- ника, остеобластах, стінках жовчних проток печінки, плаценті й лактуючій молочній залозі. Вона каталізує відщеплення фоссфорної кислоти від її органічних сполук; назву отримала у зв'язку з тим, що оптимум рН ЛФ лежить у лужному середовищі (рH 8,6-10,1). Фермент міститься на клітинній мембрані й бере участь у транспорті фроссрору [8]. Активність ЛФ у сироватці крові становить загальну активність її ізоорерментів, що містяться в печінці, кістках, нирках, слизовій оболонці кишечника та плаценті [4]. Печінкова і кісткова фрракції ЛФ завжди є в сироватці крові дорослих, причому особливо високою буває активність печінкової фрракції (за винятком вагітних, у яких в III триместрі половину кількості ЛФ продукує плацента). Активність кишкової фрракції у нормі виявляється майже винятково в осіб із групою крові В (III) і 0 (I) і не перевищує 10 \%. Підвищення ії відзначається при захворюваннях печінки [10].

Відхилення від норми. Підвищення активності ЛФ можливе при багатьох захворюваннях, але найчастіше воно спостерігається при ураженні скелетних м'язів і холестазі, що спричинила обструкція внутрішньо- або позапечінкових жовчних проток. При багатьох гострих захворюваннях печінки активність ЛФ підвищується до того, як підвищиться рівень білірубіну. Помірне збільшення активності ЛФ характерне для гострого запального процесу в печінці при цирозі, інфрекційному мононуклеозі та вірусному гепатиті, воно спостерігається також при остеомаляції та рахіті, зумовленому недостатністю вітаміну В. Дуже високі показники активності ЛФ спостерігаються при обструкції жовчних шляхів пухлиною, запальним інфільтратом або фріброзним процесом, при хворобі Педжета, обширних метастазах у кістках і гіперпаратиреозі [12]. Різко зростає ії̈ активність при отруєнні алкоголем на тлі хронічного алкоголізму. Вона може підвищуватися при застосуванні ЛП, що містять речовини, які проявляють гепатотоксичний ефект (тетрациклін, парацетамол, сренацетин, меркаптопурин, саліцилати та ін.). Приблизно у половини хворих на інфекційний моно- 
нуклеоз у перший тиждень захворювання відзначається підвищення активності ЛФ [5].

У жінок, які приймають протизаплідні препарати, що містять естроген і прогестерон, може розвинутися холестатична жовтяниця та підвищитися активність ЛФ. Дуже високі цифрри активності ферменту бувають у жінок із прееклампсією, що є наслідком ушкодження плаценти. Низька активність ЛФ у вагітних свідчить про недостатність розвитку плаценти. Низька активність ЛФ у сироватці крові відзначається при гіпофросфатемії, білковій і магнієвій недостатності, гіпотиреозі, цинзі [7].

Кисла фросоратаза (КФ) - фрермент, що міститься майже у всіх тканинах організму людини. Він допомагає прискорити ряд біохімічних реакцій щодо розпаду сполук, які містять у своєму складі фросфор. Цей фрермент є в клітинах крові, селезінці, печінці, нирках і кістках. Ці тканини - основне джерело кислої фросфратази у жінок [9].

Щоб припинити дію метотрексату, використовують так званий лейковориновий захист (лейковорин, цитроворум, фолінат кальцію). Препарати типу лейковорину відновлюють метаболізм фолатів, запобігають ушкодженню кісткового мозку, захищаючи гемопоез. Лейковорин попереджає можливу токсичну дію метотрексату при введенні його у високих дозах, а також купірує ті токсичні явища, що розвинулися від звичайних доз метотрексату [11].

Метою дослідження було вивчити токсичний вплив метотрексату на експериментальних тварин залежно від дози та оцінити захисний ефект кальцію фолінату після одноразового та дворазового введень метотрексату.

МАТЕРІАЛИ І МЕТОДИ Роботу виконано на 54 лабораторних білих щурах, яких утримували у стандартних умовах віварію. Було відібрано статевозрілих невагітних

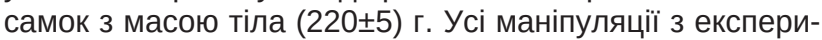
ментальними тваринами проводили із дотриманням правил Європейської конвенції про захист хребетних тварин, що використовуються для дослідних та інших наукових цілей (Страсбург, 1986). Піддослідних тварин поділили на 9 груп по 6 тварин.

Першу групу склали 6 здорових статевозрілих невагітних самок. У дослідні групи ввійшли тварини, яким вводили метотрексат в дозі 1 мг/кг внутрішньом'язово. Рівень ЛФ і КФ визначали на 3 добу (друга група) та 7 добу (третя група). До четвертої та п'ятої груп ввійшли тварини, які після одноразового введення метотрексату внутрішньом'язово в дозі 1 мг/кг додатково отримували кальцію фролінат в дозі 0,1 мг/кг через 24 год після першої ін'єкції, виведення 3 експерименту відповідно на 3 та 7 доби. щурам, які увійшли до шостої та сьомої груп, вводили метотрексат двічі, через 7 днів після першої ін'єкції у вищезазначеній дозі, виведення 3 експерименту на 3 та 7 доби після останнього введення метотрексату. Щурам восьмої та дев'ятої груп вводили дворазово метотрексат та кальцію фролінат через 24 год після ін'єкції та визначали рівень ЛФ і КФ на 3 та 7 доби.
Статистичну обробку результатів виконано у відділі системних статистичних досліджень ДВНЗ “Тернопільський державний медичний університет імені І. Я. Горбачевського МОЗ України" в програмному пакеті StatSoft STATISTICA.

РЕЗУЛЬТАТИ ДОСЛІДЖЕНЬ ТА ЇХ ОБГОВОРЕННЯ Аналізуючи отримані результати з таблиці, звертає на себе увагу достовірна різниця між показниками контрольної групи щурів та дослідних.

Порівнюючи рівень кислої сроссратази у контрольній групі $(8,28 \pm 0,33)$ та при одноразовому введенні метотрексату на 3 та 7 доби, зріс на 110,46 \% $(17,43 \pm 0,72)$ та $130,6 \%(19,1 \pm 0,48)$, p<0,001. Тоді як при використанні КФ (у четвертій та п'ятій групах) цей показник зріс лише на $73,8 \%(14,4 \pm 0,97)$ та 91,3 \% $(15,85 \pm 1,18)$, р<0,001 проти $(8,28 \pm 0,33)$ - у щурів контрольної групи. Відповідно, порівнюючи другу та третю групи з четвертою і п'ятою групами, кількість кислої фросфатази зменшилася при використанні КФ на 33,66 \% на 3 добу, р<0,05 та на 39,3 \% на 7 добу, p<0,05.

При дворазовому введенні метотрексату в шостій та сьомій групах ЛФ збільшилася на $123 \%(18,53 \pm 1,04)$ та $135,45(19,5 \pm 0,99)$, р<0,001 порівняно 3 контрольною групою $(8,28 \pm 0,33)$. Достовірної різниці між показниками другої, третьої груп та шостої, сьомої груп не виявлено, p>0,10. Простежується закономірність у зменшенні рівня кислої фросфратази при використанні КФ. Так, у восьмій та дев'ятій групах він склав $(14,22 \pm 0,26)$ та $(15,77 \pm 0,31)$ повірняно $3(18,53 \pm 1,04)$ та $(19,5 \pm 0,99), p<0,001$ у групах, де не використовували КФ, цей показник зменшився на 19,7 $\%$ на 3 та 33,4 \% на 7 добу.

Рівень лужної фроссратази у контрольній групі склав $(166,6 \pm 2,56)$ та при одноразовому введенні метотрексату на 3 та 7 доби зріс на 36,1\% $(226,7 \pm 7,11)$ та $57,7 \%$ $(262,7 \pm 9,46), p<0,001$. Тоді, як при використанні КФ (у четвертій та п'ятій групах) цей показник зріс лише на 21,6\% $(202,5 \pm 9,56)$ та $7 \%(178,3 \pm 1,75)$, р<0,001. Відповідно, порівнюючи другу та третю групи з четвертою і п'ятою групами, кількість ЛФ зменшилася при використанні КФ на $14,5 \%$ на 3 добу, p<0,1 та на 50,7 \% на 7 добу, p<0,001.

Дворазове введення метотрексату в шостій та сьомій групах збільшило рівень лужної фросфратази на 52,68 \% $(254,37 \pm 10,0)$ та $60,87 \%(268,02 \pm 2,25)$ р <0,001 порівняно 3 контрольною групою $(166,6 \pm 2,56)$. Простежується достовірна різниця між показниками другої та шостої груп. Так, на 3 добу рівень лужної фросфратази збільшився на $16,59 \%, p<0,001$ при дворазовому введенні метотрексату, а на 7 добу цей показник збільшився лише на 3,17\%, p>0,10, що немає достовірної різниці. Простежується закономірність у зменшенні рівня лужної фоосфатази як і кислої фоосфатази при використанні КФ. Так, у восьмій та дев'ятій групах рівень лужної фросфратази склав $(205,88 \pm 11,47)$ та $(172,43 \pm 2,35)$ повірняно 3 шостою та сьомою групами $(254,37 \pm 10,0)$, p<0,05 та $(268,02 \pm 2,25)$, p<0,001, цей показник зменшився на 29,1 \% на 3 добу та $57,37 \%$ на 7 добу.

Таблиця. Рівень кислої та лужної фосфатаз у щурів залежно від дози метотрексату та використання кальцію фолінату

\begin{tabular}{|c|c|c|c|c|c|c|c|c|c|}
\hline \multirow[t]{2}{*}{ Показник } & \multirow[t]{2}{*}{ Контроль } & \multicolumn{2}{|c|}{$\begin{array}{l}\text { Метотрексат, } \\
1 \text { введення }\end{array}$} & \multicolumn{2}{|c|}{$\begin{array}{c}\text { Метотрексат плюс } \\
\text { лікування, } \\
1 \text { введення }\end{array}$} & \multicolumn{2}{|c|}{$\begin{array}{l}\text { Метотрексат, } \\
2 \text { введення }\end{array}$} & \multicolumn{2}{|c|}{$\begin{array}{c}\text { Метотрексат, } \\
2 \text { введення плюс лікування }\end{array}$} \\
\hline & & 3 доба & 7 доба & 3 доба & 7 доба & 3 доба & 7 доба & 3 доба & 7 доба \\
\hline Кисла фросфатаза & $8,28 \pm 0,33$ & $17,43 \pm 0,72$ & $19,1 \pm 0,48$ & $14,4 \pm 0,97$ & $15,85 \pm 1,18$ & $18,53 \pm 1,04$ & $19,5 \pm 0,99$ & $14,22 \pm 0,26$ & $15,77 \pm 0,31$ \\
\hline Лужна фросфратаза & $166,6 \pm 2,56$ & $226,7 \pm 7,11$ & $262,7 \pm 9,46$ & $202,5 \pm 9,56$ & $178,3 \pm 1,75$ & $254,37 \pm 10,0$ & $268,02 \pm 2,25$ & $205,88 \pm 11,47$ & $172,43 \pm 2,35$ \\
\hline
\end{tabular}


Висновки Даний експеримент показав збільшення рівня кислої та лужної сроссратаз у щурів при внутрішньом'язовому введенні метотрексату при позаматковій вагітності. Дворазове введення метотрексату підвищує рівень печінкових фрерментів у крові, що показує токсичний вплив цитостатику на печінку. Використання кальцію фролінату зменшує побічну дію основного препарату, що показано достовірною різницею між дослідними групами щурів. Отже, корекцію метаболічних порушень при консервативному лікуванні позаматкової вагітності можливо проводити антидотом метотрексату - кальцію фолінатом.

Перспективи подальших досліджень На нашу думку, в дослідних групах достовірна різниця рівня кислої та лужної фоссфатаз показує захисний вплив кальцій фролінату, що дозволяє припустити можливість використання даного прерапату в жінок із позаматковою вагітністю, яких лікували метотрексатом для попередження токсичної дії на печінку.

\section{СПИСОК ЛІТЕРАТУРИ}

1. Бодур С. Какова роль первичного метотрексата лечения внематочной беременности / С. Бодур, Р. Гвидо // Am J Obstet Gynecol. - 2014. - № 210 (4). - C. 379-380.

2. Почти трагедия: тяжелая метотрексат токсичность в гемодиализа пациента лечили от внематочной беременности / Н. Виллнер, С. Шторх, Т. Фадмор, Е. Шиффф // Eur. J. Clin. Pharmacol. - 2014. - № 70 (3). - C. 261-263. DOI 10.1007/s00228013-1608-3. Epub 201326 ноября.

3. Гуриев Т. Д. Внематочная беременность / Т. Д. Гуриев, И. С. Сидорова. - М. : Практическая гинекология, 2007. - 96 с.

4. Запорожан В. М. Оперативна ендоскопія в гінекологічній клініці / В. М. Запорожан // Лікування та діагностика. - 1998. № 1. - C. 52-55.

5. Камінський В. В. Сучасні етіологічні фактори позаматкової вагітності / В.В.Камінський, Ю. О. Туренко // Буковинський медичний вісник. - 2003. - Т. 7, № 4. - С. 176-178.

6. Метотрексат - процент успеха при прогрессирующей внематочной беременности: новая оценка / Л. Закар, У. Джил, ж. Aмер-Alshiek [и др.] // Am J Obstet Gynecol. - 2014. - PII S0002-9378 (14).

7. Маркін С. Б. Позаматкова вагітність / С. Б. Маркін, О. О. Матвієнко, С. А. Маркін. - Львів, 1999. - 106 с.
8. Отри А. М. Медикаментозное лечение внематочной беременности: есть ли что-то новое? / А. М. Отри // Obstet Gynecol. - 2013. - № 122 (4). - C. 733-734. DOI 10.1097.

9. Внематочная беременность / А. Н. Стрижаков, А. И. Давыдов, М. Н. Шахламова, Л. Д. Белоцерковская. - М. : Медицина, 1998. - 201 с.

10. Сяо С. Влияние метотрексата для лечения в внематочной беременности на состояние овариального резерва / С. Сяо, М. Н. Даан // Fertil Steril. - 2014. - № 101 (4). - С. 23.

11. Системное использование метотрексата: эффрективная альтернатива хирургии для лечения неразвивающейся внематочной беременности / Р. Тальвар, К. Сандип, Б. С. Дуггал [и др.]. // Med J Вооруженные силы Индии. - 2013. - № 69 (2). - Р. 130-133.

12. Baldvinsdottir A. Incidence and management of ectopic pregnancy in Iceland 2000-2009 / A. Baldvinsdottir, J. A. Gudmundsson, R. T. Geirsson // Laeknabladid. - 2013. - No 99 (12). - P. 565-570.

13. Association of plasma leptin, homocysteine and nitric oxide levels with the presence and unstability of coronary artery disease I G. Basati, A. E. Razavi, S. Abdi, N. Sarrafzedegan // Biomark Med. - 2014. - Vol. 8 (3). - P. 405-412. doi: 10.2217/bmm.13.131.

14. Seremak-Mrozikiewicz A. Metafolin--alternative for folate deficiency supplementation in pregnant women / A. SeremakMrozikiewicz // Ginekol. Pol. - 2013. - Vol. 84 (7). - P. 641-646.

Отримано 04.07.17

(CYu. B. Yakymchuk, V. Y. Koptiukh, O. M. Yakymchuk

I. Horbachevsky Ternopil State Medical University

\section{CORRECTION OF METABOLIC DISORDERS DURING CONSERVATIVE TREATMENT OF ECTOPIC PREGNANCY}

Summary. According to epidemiological studies in economically developed countries, the frequency of ectopic pregnancies (EP) is $1.2-2.0 \%$ of the total number of pregnancies and $0.8-2.4 \%$ of births and is 4 th among the causes of maternal mortality.

The aim of the study - to investigate the toxic effects of methotrexate on experimental animals, depending on the dose, and assess the protective effect of calcium folinate after single and double administration of methotrexate.

Materials and Methods. The work was performed on 54 laboratory white rats, which were kept under standard vivarium conditions. Selected sexually mature non-pregnant females with body weight $(220 \pm 5) \mathrm{g}$. All manipulations with experimental animals were conducted in accordance with the rules of the European Convention for the Protection of Vertebrate Animals used for experimental and other scientific purposes (Strasbourg, 1986). Experimental animals were divided into 9 groups of 6 animals.

Results and Discussion. We examined the endogenous intoxication index in 54 experimental rats against the background of single and double administration of methotrexate at a dose of $1 \mathrm{mg} / \mathrm{kg}$ at 3 and 7 days. The protective effect of calcium folinate in a dose of $0.1 \mathrm{mg} / \mathrm{kg}$, which was administered 24 hours after the injection of methotrexate, was investigated. This experiment showed an increase in the level of acidic and alkaline phosphatases in rats when intramuscular administration of methotrexate during ectopic pregnancy. The use of calcium folinate reduces the side effect of the main drug, which is shown by a significant difference between experimental groups of rats.

Conclusions. This experiment showed an increase in the level of acidic and alkaline phosphatases in rats when intramuscular administration of methotrexate during ectopic pregnancy. Correction of metabolic disorders in the conservative treatment of ectopic pregnancy may be carried out by an antidote of methotrexate - calcium folinate.

Key words: methotrexate; acid phosphatase; alkaline phosphatase; calcium folio. 
СЮ. Б. Якимчук, В. И. Коптюх, А. Н. Якимчук

ГВУз “Тернопольский государственный медицинский университет имени И. Я. Горбачевского” КОРРЕКЦИИ МЕТАБОЛИЧЕСКИХ НАРУШЕНИЙ ПРИ КОНСЕРВАТИВНОМ ЛЕЧЕНИИ ВНЕМАТОЧНОЙ БЕРЕМЕННОСТИ

Резюме. Согласно данным эпидемических исследований, в экономически развитых странах частота внематочной беременности (ПВ) составляет 1,2-2,0 \% от общего количества беременностей и 0,8-2,4 \% от родов и занимает 4 место среди причин материнской смертности.

Цель исследования - изучить токсическое воздействие метотрексата на экспериментальных животных в зависимости от дозы и оценить защитный эффрект кальция фолината после однократного и двукратного введения метотрексата.

Материалы и методы. Работа выполнена на 54 лабораторных белых крысах, которых удерживали в стандартных условиях

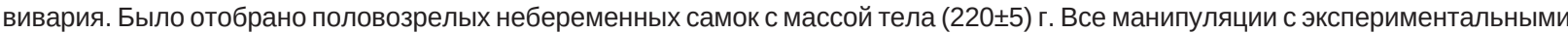
животными проводили с соблюдением правил Европейской конвенции о защите позвоночных животных, используемых для исследовательских и других научных целей (Страсбург, 1986). Подопытных животных разделили на 9 групп по 6 животных. Результаты исследований и их обсуждение. Нами было изучено индекс эндогенной интоксикации в 54 исследовательских крыс на фроне однократного и двукратного введения метотрексата в дозе 1 мг/кг в 3 и 7 сутки. Исследовано защитное действие кальция фолината в дозе 0,1мг/кг, который вводился через 24 ч после инъекции метотрексата. Данный эксперимент показал увеличение уровня кислой и щелочной фросфратаз у крыс при внутримышечном введении метотрексата при внематочной беременности. Использование кальция фолината уменьшает побочное действие основного препарата, что показано достоверной разницей между исследовательскими группами крыс.

Выводы. Данный эксперимент показал увеличение уровня кислой и щелочной фоосратаз у крыс при введении метотрексата при внематочной беременности. Коррекцию метаболических нарушений при консервативном лечении внематочной беременности можно проводить антидотом метотрексата - кальция фолинатом.

Ключевые слова: метотрексат; кислая фоссратаза; щелочная фросфратаза; кальция фролинат. 